\title{
Analisis Efektivitas Pelaksanaan Bauran Promosi \\ Pada Hotel The Lombok Lodge \\ Dengan Menggunakan Metode Epic Model
}

\author{
Baiq Candra Herawati ${ }^{1}$, Siti Soraya ${ }^{2}$ \\ Dosen Universitas Bumigora
}

Email :

candrah@universitasbumigora.ac.id1, sitisorayaburhan@universitasbumigora.ac.id²

\begin{abstract}
Abstrak
Dalam pelaksanaan promosi hotel The Lombok Lodge, hotel tersebut menerapkan promosi melalui periklanan, promosi penjualan, penjualan pribadi dan pemasaran langsung, dimana periklanan dilakukan melalui katalog, promosi penjualan dilakukan melalui pemberian potongan harga sewa, penjualan pribadi dilakukan melalui agen marketing dan pemasaran langsung dilakukan melalui customer service. Terdapat beberapa metode yang dapat digunakan untuk menganalisis efektivitas bauran promosi berdasarkan dampak komunikasi yang ditimbulkan, yaitu: MMP (Media Mix Planing), CRI (Costomer response index), DRM (Direct rating method) dan EPIC Model.EPIC Model yang digunakan untuk mengukur efektivitas bauran promosi yang mencakup empat dimensi kritis, yaitu: empati (empathy), persuasi (persuasion), dampak (dampak) dan komunikasi (communication).Pada penelitian ini jenis data yang digunakan adalah data kualitatif yang dikuantitatifkan.Jenis penelitian yang digunakan adalah penelitian deskriptif eksploratif.Secara keseluruhan pelaksanaan bauran promosi pada hotel The Lombok Lodge telah efektif, terbukti dari hasil analisis EPIC Model secara keseluruhan sebesar 4.01, nilai tersebut masuk dalam rentang skala penilaian $3.41-4.20$ (Efektif).
\end{abstract}

Kata kunci: efektivitas, bauran promosi, hotel The Lombok Lodge. 


\section{Pendahuluan}

Dalam pelaksanaan promosi hotel The Lombok Lodge, hotel tersebut menerapkan promosi melalui periklanan, promosi penjualan, penjualan pribadi dan pemasaran langsung, dimana periklanan dilakukan melalui katalog, promosi penjualan dilakukan melalui pemberian potongan harga sewa, penjualan pribadi dilakukan melalui agen marketing dan pemasaran langsung dilakukan melalui customer service.

Durianto (2003), menyebutkan bahwa terdapat beberapa metode yang dapat digunakan untuk menganalisis efektivitas bauran promosi berdasarkan dampak komunikasi yang ditimbulkan, yaitu: MMP (Media Mix Planing), CRI (Costomer response index), DRM (Direct rating method) dan EPIC Model. MMP merujuk pada penggunaan dua atau lebih bentuk media yang berbeda dalam sebuah rencana variabel bauran promosi, CRM merupakan hasil perkalian antara awareness (kesadaran), comprehend (pemahaman konsumen), interest (ketertarikan), intentions (maksud untuk membeli), dan action (bertindak membeli). DRM disebut juga Metode Penentuan Peringkat Langsung untuk menguji pesan promosi, kemudian konsumen diberi beberapa alternatif promosi dimana mereka diminta untuk menentukan peringkat masing-masing promosi dan dalam metode ini semakin tinggi peringkat yang diperoleh sebuah promosi maka semakin tinggi pula kemungkinan promosi tersebut efektif, serta EPIC Model yang digunakan untuk mengukur efektivitas bauran promosi yang mencakup empat dimensi kritis, yaitu: empati (empathy), persuasi (persuasion), dampak (dampak) dan komunikasi (communication).

Diantara keempat metode analisis efektivitas bauran promosi di atas, Durianto (2003) mengemukakan, EPIC Model memiliki kelebihan yaitu: untuk menguji dimensi EPIC Model cukup menggunakan satu media saja pada setiap variabel bauran promosi dan EPIC Model dapat menganalisis efektivitas masing-masing dimensinya secara terpisah sehingga dapat diketahui pada dimensi yang manakah sebuah variabel bauran promosi memiliki kelemahan dalam pencapaian tujuannya, serta selanjutnya dibuat strategi baru untuk memperbaikinya. Berdasarkan uraian diatas maka peneliti tertarik untuk melakukan penelitian tentang "Analisis Efektivitas Pelaksanaan Bauran Promosi Pada Hotel The Lombok Lodge Dengan Menggunakan Metode Epic Model”.

\section{Kajian Teori}

\subsection{Efektivitas Promosi}

Saksono (1984), mengemukakan efektivitas adalah seberapa besar tingkat kelekatan output yang dicapai dengan output yang diharapkan dari sejumlah input. Steers (1985:46), efektivitas adalah sejauh mana organisasi melaksanakan seluruh tugas pokoknya atau mencapai semua sasaran. Gibson (2002), efektivitas adalah pencapaian sasaran yang telah disepakati atas usaha bersama. Hidayat (1986), efektivitas adalah suatu ukuran yang 
menyatakan seberapa jauh target (kuantitas, kualitas dan waktu) telah tercapai. Dimana makin besar presentase target yang dicapai, makin tinggi efektivitasnya.

Efektivitas bauran promosi dapat diukur dengan menggunakan EPIC model. Durianto (2003), mengemukakan bahwa EPIC model dikembangkan oleh AC Niclsen, salah satu perusahaan peneliti pemasaran terkemuka di dunia. EPIC model mencakup empat dimensi krisis yaitu: empati, persuasi, dampak dan komunikasi (empathy, persuasion, impact and communication-EPIC). Berikut akan dipaparkan dimensi-dimensi dalam EPIC model, yakni:

1. Dimensi empati (empathy)

Dimensi empati memberikan informasi yang berharga tentang daya tarik suatu merek. Empati merupakan keadaan mental yang membuat seseorang mengidentifikasikan dirinya atau merasa dirinya pada keadaan perasaan atau fikiran yang sama dengan orag atau kelompok lain (Kamus besar bahasa Indonesia, 2003).

Empati melibatkan afeksi dan kognisi konsumen, menurut Peter dan Olson (1996), afeksi dan kognisi mengacu pada dua tipe tanggapan internal psikologis yang dimiliki konsumen terhadap rangsangan lingkungan dan kejadian yang berlangsung. Dalam bahasa yang lebih sedehana, afeksi melibatkan perasaan, sementara kognisi melibatkan pemikiran. Variasi tanggapan afektif dapat berupa penilaian positif, negatif, menyenangkan atau tidak menyenangkan dan konsumen dapat merasakan empat jenis tanggapan afektif yaitu emosi, perasaan khusus, suasana hati dan evaluasi yang bebeda dalam tingkat intensitas dan daya improvisasinya. Menurut Niclsen dalam Rangkuti (2002), pertanyaan kuesioner dimensi empati biasanya mempertanyakan bagaimana pendapat responden dan seberapa suka responden terhadap bauran promosi yang diterapkan.

2. Dimensi persuasi (persuasion)

Dimensi persuasi menginformasikan apa yang dapat diberikan suatu iklan untuk peningkatan atau penguatan karakter suatu merek, sehingga pemasang promosi memperoleh pemahaman tentang dampak promosi terhadap keinginan konsumen untuk membeli serta memperoleh kemampuan suatu promosi dalam mengembangkan daya tarik suatu produk.

Persuasi adalah perubahan kepercayaan, sikap dan keinginan berprilaku yang disebabkan satu komunikasi promosi. Proses persuasi yang akan dipakai ditentukan dengan tingkat keterlibatan konsumen dalam pesan produk (Peter dan Olson, 1996). Menurut Niclsen dalam Rangkuti (2002), pertanyaan kuesioner dimensi persuasi biasanya mempertanyakan seberapa besar ketertarikan responden dan seberapa ingin responden melakukan pembelian/ penyewaan setelah melihat promosi yang diterapkan.

3. Dimensi dampak (impact)

Dimensi dampak menunjukkan apakah suatu produk/jasa dapat terlihat menonjol dibandingkan produk/jasa yang lain pada kategori yang serupa dan apakah suatu promosi mampu melibatkan konsumen dalam pesan yang disampaikan. Dampak (impact) yang diinginkan dari hasil promosi adalah jumlah pengetahuan produk (product knowdge) yang dicapai konsumen 
melalui tingkat keterlibatan (involment) dengan produk/jasa dan proses pemilihan. Konsumen memiliki tingkat pengetahuan produk/jasa (level of product knowledge) yang berbeda-beda, yang dapat digunakan untuk menterjemahkan informasi baru dan membuat pilihan pembelian. Konsumen dapat memiliki empat tingkat pengetahuan produk, yaitu: kelas produk, bentuk produk, merek dan model (Peter dan Olson, 1996).

Selain itu konsumen juga dapat memiliki tiga jenis pengetahuan produk/jasa, yaitu pengetahuan tentang ciri atau karakter produk/jasa, konsekuensi atau manfaat positif menggunakan poduk/jasa dan nilai yang akan dipuaskan atau dicapai suatu produk/jasa. Keterlibatan (involvement) mengacu pada persepsi tentang konsumen tentang pentingnya atau relevansi personal suatu objek, kejadian atau aktifitas. Konsumen yang melihat bahwa suatu produk/jasa memiliki konsekuensi yang elevan secara pribadi, maka konsumen dikatakan terlibat dengan produk/jasa tersebut dan memiliki hubungan dengan produk tersebut

Konsekuensi dengan suatu produk atau jasa memiliki aspek kognitif maupun pengaruh. Secara kognitif, yang termasuk dalam keterlibatan adalah pengaruh, seperti evaluasi produk/jasa. Jika keterlibatan suatu produk/jasa tinggi, maka orang akan mengalami tanggapan pengaruh yang lebih kuat, seperti emosi dan perasaan yang kuat. Keterlibatan dapat berkisar dari tingkat yang rendah hingga ke tingkat yang tinggi, keterlibatan adalah status motivasi yang menggerakkan serta mengarahkan proses kognitif dan perilaku konsumen pada saat mereka membuat keputusan (Peter dan Olson, 1996). Menurut Niclsen dalam Rangkuti (2002), pertanyaan kuesioner dimensi dampak biasanya mempertanyakan perbandingan antara objek penelitian dengan objek lain dan dampak dari dilaksanakan bauran promosi tersebut.

4. Dimensi komunikasi (communication)

Dimensi komunikasi memberikan informasi tentang kemampuan konsumen dalam mengingat pesan utama yang disampaikan, pemahaman konsumen, serta kekuatan kesan yang ditinggalkan pesan tersebut. Perspektif pemrosesan kognitif adalah inti untuk mengembangkan strategi pemasaran yang berhasil yang merupakan permasalahan komunikasi.

Proses dimulai ketika sumber komunikasi promosi menentukan informasi apa yang harus dikomunikasikan, kemudian meng-enkoding (menyandi)pesan tersebut dalam bentuk simbol-simbol yang paling tepat (menggunakan kata, gambar atau tindakan). Kemudian, pesan ditransmisikan ke sebuah penerima melalui berbagai media, seperti pertunjukan televisi, penawaran via pos, billboard atau majalah. Penerima atau konsumen, jika digiring ke suatu promosi, harus men-decoding (menerjemahkan maknanya). Kemudian, konsumen dapat mengambil tindakan, seperti pergi ke hotel untuk melakukan penyewaan (Peter dan Olson, 1996)..

Dua tahapan model komunikasi sangat dibutuhkan, khususnya demi keberhasilan penerapan strategi promosi. Tahapan pertama terjadi ketika pemasar menciptakan komunikasi promosi untuk meng-encoding suatu makna. Tahapan kedua adalah pen-decoding-an, yaitu komsumen masuk dan 
memahami informasi dalam komunikasi promosi dan mengembangkan interpretasi pribadi mereka terhadap makna yang ditangkap (Peter dan Olson, 1996). Menurut Niclsen dalam Rangkuti (2002), pertanyaan kuesioner dimensi komunikasi biasanya mempertanyakan seberapa mengerti responden dan seberapa kenal responden terhadap bauran promosi yang diterapkan.

\subsection{Bauran Promosi}

Menurut Swastha (2007:343), strategi promosi ada 4 bentuk, yaitu: Periklanan, Personal selling, publisitas dan promosi penjualan. Sedangkan menurut Kotler (1997: 153), proses keputusan pembelian dipengaruhi oleh rangsangan pemasaran dan rangsangan lain. Bauran promosi meliputi periklanan (advertising), penjualan pribadi (personal selling), hubungan masyarakat (public relation) dan publisitas (publicity), promosi penjualan (sales promotion), dan pemasaran langsung (direct marketing), adalah bagian dari rangsangan pemasaran yang merupakan variabel yang dapat dikontrol oleh perusahaan.

A. Periklanan (advertising)

Menurut Swastha (2007:343), periklanan adalah bentuk presentasi dan promosi non pribadi tentang ide, barang dan jasa yang dibayar oleh sponsor tertentu. Periklanan memiliki empat fungsi utama, yaitu: menginformasikan khalayak tentang seluk beluk produk/jasa, mempengaruhi khalayak untuk membeli/menyewa, menyegarkan informasi yang telah diterima khalayak dan menciptakan suasana yang menyenangkan sewaktu khalayak menerima dan mencerna informasi.

Media dalam konteks periklanan memiliki definisi tersendiri, salah satunya dikemukakan oleh Wells, Burnett dan Moriarty (1982), sebagai berikut: "The media are channels of communication that carry the messages from the adverteser to the audience" (Media adalah sarana komunikasi yang membawa pesan-pesan dari pengiklan kepada konsumennya). Media iklan antara lain: media cetak (surat kabar, majalah, tabloid), media siar (televisi, radio, bioskop), media luar ruangan (billboard, balon, pernak pernik dan lain sebagainya), media ruang dalam (signboard dalam stadium, mall, gym, ice ring dan lain sebagainya), media pertemuan (layar tancap, pertunjukan kesenian, seminar), media internet, media transit (bus, angkutan kota, kereta api, kapal laut, pesawat).

B. Promosi Penjualan (sales promotion)

Kotler (1997), mendefinisikan bahwa promosi penjualan merupakan kegiatan pemasaran selain penjualan oleh perorangan, advertensi, dan publisitas, yang mendorong konsumen untuk membeli dan mendorong keberhasilan agen penjual, seperti misalnya pajangan, pertunjukan, eksibisi, demonstrasi serta berbagai usaha penjualan yang sifatnya tidak terus menerus dan tidak dilaksanakan secara rutin.

Pada pelaksanaannya, Swastha (2007), menyatakan bahwa promosi penjualan dilakukan dengan berbagai macam cara, yaitu:

1. Promosi konsumen 
Promosi konsumen ialah promosi yang ditujukan pada konsumen akhir, dapat berupa:

a. Contoh, yaitu contoh produk yang diberikan kepada konsumen dengan harapan mereka menerimanya serta menggunakannya, dapat diberikan secara langsung kepada konsumen atau digabungkan dengan produk yang sudah dikenal konsumen.

b. Kupon, yaitu secarik kertas berstempelkan perusahaan yang memberikan hak kepada pemegangnya untuk mendapat pemotongan harga dalam membeli produk/jasa dengan harga yang lebih murah, cara penyampaian kepada konsumen sama dengan contoh di atas yaitu dapat secara langsung atau disatukan dengan produk lain yang sudah dikenal.

c. Pengembalian uang ganti rugi, yaitu produsen bersedia mengembalikan uang pembeli apabila kalau ternyata produk/jasa yang dijualnya tidak memuaskan lagi bagi konsumen.

d. Promosi harga, yaitu potongan harga dari harga biasa, konsumen dapat mengetahui langsung pada bungkus atau package dari produk yang dibelinya.

e. Stempel perdagangan, yaitu pemberian kupon-kupon dengan cap dagang perusahaan, pada waktu terjadinya pembelian barang. Apabila kupon sudah terkumpul dalam jumlah tertentu, maka dapat ditukar dengan sesuatu barang dari perusahaan tersebut.

f. Demonstrasi, yaitu perbuatan nyata dari penjualan dihadapan pembeli dimana diperlihatkan serta dijelaskan cara-cara pemakaian maupun kegunaan dan daya tahan suatu barang. Dengan cara tersebut pembeli dapat melihat bagaimana kebenaran dari advertensi suatu produk dan manfaat apa yang akan diperoleh bila membeli produk tersebut.

g. Persaingan, yaitu perusahaan memberi kesempatan kepada konsumen untuk memenangkan suatu undian yang diadakan oleh perusahaan tersebut.

2. Promosi perdagangan

Yaitu promosi yang ditujukan kepada pedagang perantara yang dapat berupa:

a. Bantuan pembelian, yaitu potongan harga yang diberikan kepada penjual sehubungan dengan pembeliannya dalam jangka waktu tertentu. Sifatnya ialah jangka pendek dan biasanya dilakukan pada perkenalan barang yang baru.

b. Bantuan yang diharapkan, yaitu komisi yang diberikan oleh produsen kepada penjual untuk setiap produk yang dijualnya dengan maksud supaya penjual cepat mengisi persediaan barangnya. Berarti, dalam hal ini penjual akan mendapat premi untuk produk yang keluar dari dalam gudangnya.

c. Bantuan sebelum pembelian, yaitu potongan yang diberikan kepada penjual berdasarkan pembelian yang dilakukan sebelumnya, misalnya membeli dalam jumlah tertentu kemudian membeli lagi. 
d. Bantuan barang dagang, yaitu penggantian kerugian yang diberikan oleh produsen kepada penjual terhadap produk yang tidak sesuai dengan yang berdasarkan kontrak yang dibuat sebelumnya.

e. Kerja sama advertensi, yaitu advertensi yang dilaksanakan oleh penyalur tetapi biasanya akan diganti oleh produsen dalam jangka waktu tertertu.

f. Promosi daftar penjual, yaitu advertensi yang dilakukan oleh produsen yang menyebutkan bahwa produk dapat dibeli pada penjual-penjual tertertu. Jadi dalam hal ini penjual juga dipromosikan kepada konsumen.

g. Uang rangsangan, yaitu intensif yang diberikan kepada penyalur maupun para penjual agar mendahulukan penjualan produk perusahaan tertentu dari pada produk perusahaan lain.

h. Kontes penjual, yaitu dorongan yang diberikan oleh perusahaan dalam bentuk hadiah untuk penyalur atau para penjual yang menjual paling banyak.

i. Muatan penjual, yaitu premi yang diberikan kepada penjual untuk pembelian sejumlah barang-barang.

3. Promosi tenaga penjual

Yaitu promosi yang ditujukan kepada tenaga penjual perusahaan yang terdiri dari:

a. Bonus, yaitu pembayaran tunai kepada para penjual sebagai tambahan disamping gaji biasa karena usaha-usaha yang lebih dari biasa dalam menjual barang/jasa tersebut.

b. Kontes tenaga penjual, yaitu suatu kompetisi antara para penjual perusahaan dalam usaha untuk lebih mendorong persaingan diantara sesama mereka sehingga penjualan dapat lebih ditingkatkan.

c. Pertemuan penjual, yaitu pertemuan antara berbagai para penjual atau yang dilaksanakan oleh perusahaan dengan mengundang para penyalurnya, dengan tujuan untuk mendiskusikan bagaimana cara-cara penjualan yang lebih baik supaya terdapat peningkatan dari volume penjualan.

C. Penjualan Pribadi (personal selling)

Nickels (2000), mendefinisikan personal selling adalah interaksi antar individu, saling bertemu muka yang ditujukan untuk menciptakan, memperbaiki, menguasai dan mempertahankan hubungan pertukaran yang saling menguntungkan dengan pihak lain.

Menurut Murwarni (2009), terdapat banyak cara penjualan secara pribadi (personal selling) yang sering dilakukan, beberapa diantaranya adalah:

1. Network/jaringan

Adalah jaringan personal selling yang menyalurkan suatu poduk secara hirarkis mulai dari personal selling atas, kemudian ke tingkat-tingkat di bawahnya dan begitu seterusnya.

2. Industrial

Personal selling yang menyalurkan produk yang akan digunakan sebagai bahan baku pembuat produk lainnya. Konsumen dari personal selling jenis ini adalah pabrik/industri atau perusahaan.

3. Profesional 
Merupakan bentuk personal selling khusus yang berkaitan dengan profesi/bidang keahlian tertentu, misalnya dokter, penata rambut, dan sebagainya.

4. Konsumen

5. Adalah bentuk personal selling yang biasanya dilakukan untuk menjual produk-produk dalam kategori konsumsi yang habis dipakai sehari hari, misalnya sabun mandi, makanan, dan sebagainya.

D. Pemasaran Langsung (direct marketing)

Kotler dan Amstrong (1997), mendefinisikan pemasaran langsung merupakan komunikasi langsung dengan pelanggan individu yang dibidik secara seksama baik untuk memperoleh tanggapan segera maupun membina hubungan pelanggan yang berlangsung lama, model bisnis yang langsung ke pelanggan (direct-to-customers bussines model), harga wajar untuk kinerja tinggi, kostumisasi, layanan dan dukungan dan nilai yang unggul bagi pemegang saham.

Menurut Kotler dan Amstrong (1997), bentuk-bentuk pemasaran langsung antara lain: pemasaran tatap muka, pemasaran jarak jauh, pemasaran melalui surat langsung (faks, e-mail, voice mail), pemasaran melalui katalog (katalog cetak, video, elektronik yang dikirim kepada pelangan pilihan; disediakan di toko/dipresentasikan secara online, pemasaran melalui televisi yang menghasilkan tanggapan langsung (direct response television marketing), pemasangan iklan tanggapan langsung (direct response advertising), saluran belanja dari rumah (home shopping channel).

\section{Metode Penelitian}

Jenis penelitian yang digunakan adalah penelitian deskriptif eksploratif.Penelitian deskriptif seringkali dibedakan menjadi dua jenis berdasarkan sifat dan analisis datanya, yaitu penelitian deskriptif eksploratif dan penelitian deskriptif developmental. Penelitian deskriptif yang bersifat eksploratif bertujuan untuk menggambarkan keadaan atau status fenomena. Biasanya dilakukan dengan survey dan menjadi dasar dalam mengambil kebijakan atau penelitian lanjutan. Analisis data menggunakan statistik deskritif, prosentase atau pemaparan menggunakan kata-kata atau kalimat (Arikunto : 1989).

Dalam penelitian deskriptif biasanya hanya melibatkan variabel tunggal, tidak mengungkapkan hubungan antar variabel. Sehingga penelitian deskriptif tidak dimaksudkan untuk menguji hipotesis. Oleh karena itu hipotesis penelitian tidak diperlukan, (Asnawi dan Masyhuri:2009).Dalam penelitian ini hanya mendiskripsikan variabel bauran promosi yang diterapkan pada hotel The Lombok Lodge.

\section{Hasil Penelitian Dan Pembahasan}

\subsection{Deskripsi Penelitian}

\subsubsection{Deskripsi Objek Penelitian}


Hotel The Lombok Lodge berada di Jalan Oberoi Desa Medana Kec. Tanjung Kab. Lombok Utara - Indonesia, dengan titik koordinat 8²1'40.00" lintang selatan dan $116^{\circ} 7^{\prime} 24.00^{\prime \prime}$ bujur timur.

Hotel The Lombok Lodge memiliki satu lobby room yang asri dan luas, satu restaurant yang tertata rapi, sembilan kamar yang terpisah antara kamar yang satu dengan kamar yang lainnya, satu metting room, satu bar dan dua kolam renang yang dikamuflase hingga muka airnya terlihat seperti berada pada satu garis muka air laut, dimana keseluruhan penataannya menghadap laut lepas.

\subsubsection{Karakteristik Responden}

Jumlah responden dalam penelitian ini adalah sebanyak 160 orang wisatawan mancanegara dengan kriteria yang telah disebutkan sebelumnya. Kriteria tersebut yaitu wisatawan yang sedang menginap di hotel The Lombok Lodge yang dipilih secara acak. Berdasarkan data tersebut maka dapat diketahui karakteristik dari responden dalam penelitian ini sebagai berikut:

1. Jenis Kelamin

Berdasarkan perhitungan terhadap karakteristik responden, maka diperoleh bahwa responden berjenis kelamin laki-laki lebih banyak dari responden berjenis kelamin perempuan yakni sebesar 71.88 persen. Hal ini bisa saja terjadi karena laki-laki lebih berani melalukan perjalan wisata dibandingkan dengan perempuan.

2. Kewarganegaraan

Responden didominasi oleh responden yang berkewarganegaraan Amerika Serikat sebanyak 30 orang atau sebesar 18.75 persen. Selama masa penelitian, tidak ada responden atau konsumen yang sedang menginap yang berkewarganegaraan Indonesia (wisatawan lokal). Hal ini disebabkan karena hanya kalangan tertentu yang memilih hotel The Lombok Lodge sebagai tempat menginap mengingat harga sewa kamar hotel berkisar diatas 290US\$ per hari atau lebih kurang Rp. 2.600.000,00 per hari.

3. Kelompok usia

Responden dalam kelompok usia 36-40 tahun merupakan yang paling banyak jumlahnya yaitu sebanyak 68 orang atau sebesar 42.50 persen. Hal ini dikarenakan kisaran usia tersebut adalah usia produktif di mana wisatawan mancanegara dapat mengunjungi tempat-tempat wisata dan memiliki kemampuan finansial yang lebih dibanding kelompok usia yang lain.

4. Tingkat pendidikan terakhir

Responden yang tingkat pendidikan terakhirnya Sekolah Lanjutan Tingkat Atas (senior hight school) merupakan responden yang paling banyak jumlahnya yaitu sebanyak 136 orang atau sebesar 85.00 persen. Hal ini dikarenakan tingkat pendidikan tersebut merupakan tingkat pendidikan minimal dari masyarakat global/masyarakat dunia saat ini.

5. Pekerjaan

Responden yang bekerja sebagai wiraswasta memiliki jumlah terbanyak yaitu sebanyak 75 orang atau sebesar 46.88 persen. Hal ini dikarenakan banyak 
para wisatawan mancanegara melakukan perjalanan wisata untuk bersantai setelah melakukan aktifitas bisnis yang padat terutama para wiraswastawan.

6. Pendapatan per bulan

Berdasarkan hasil pengolahan, maka dapat diketahui bahwa pendapatan responden terbanyak yaitu diatas Rp. 15.000.000,00 per bulan dengan jumlah responden sebanyak 106 orang atau sebesar 66.25 persen. Hal ini dikarenakan harga menginap di hotel The Lombok Lodge cukup mahal yang hanya dapat dijangkau oleh para konsumen yang memiliki pendapatan per bulan yang cukup besar.

7. Tujuan menginap

Berdasarkan hasil pengolahan data, maka dapat diketahui bahwa karakteristik responden berdasarkan tujuan menginap, responden yang menginap untuk berlibur merupakan responden terbanyak yakni sebanyak 153 orang atau sebesar 95.63 persen. Hal ini dikarenakan keberadaan hotel The Lombok Lodge sejak awal memang berorientasi untuk tempat berlibur para wisatawan.

\subsection{Uji Validitas Dan Reliabilitas}

Pengujian validitas dan realibilitas terhadap instrumen kuesioner dilakukan untuk menjamin bahwa instrumen tersebut akurat dan dapat dipercaya, serta dapat diandalkan jika digunakan sebagai alat dalam pengumpulan data. Dalam penelitian ini, untuk uji validitas digunakan metode statistik Product Moment Pearson, sedangkan alat uji reliabilitas digunakan koofisien reliabilitas (Cronbach's Alpha).

\subsubsection{Uji Validitas}

Dari hasil pengujian validitas menunjukkan bahwa hasil pengujian validitas untuk kuesioner penelitian secara keseluruhan valid. Hal ini ditujunkan oleh penilaian r-hitung dari keseluruhan item lebih besar dari nilai

r-kritis. Ketentuan validitas item pengukuran pada penelitian ini telah memenuhi syarat untuk dikatakan valid, yaitu jika r-hitung $>r$-kritis.

\subsubsection{Uji Reliabilitas}

Dari hasil pengujian reliabilitas menunjukkan bahwa hasil pengujian reliabilitas untuk kuesioner penelitian secara keseluruhan reliabel. Hal ini ditujunkan oleh penilaian $\mathrm{r}_{11}$-hitung dari keseluruhan item lebih besar dari nilai $\mathrm{r}_{11-k r i t i s}$ Ketentuan reliabilitas item pengukuran pada penelitian ini telah memenuhi syarat untuk dikatakan reliabel, yaitu jika $\mathrm{r}_{11-h i t u n g}>\mathrm{r}_{11-k r i t i s}$.

\subsection{Statistik Deskriptif Tanggapan Responden Tentang Bauran Promosi}

Analisis ini dilakukan untuk mendapatkan gambaran deskriptif mengenai responden penelitian ini, khususnya mengenai variable-variabel penelitian yang digunakan. Analisis ini dilakukan dengan menggunakan teknik analisis indeks untuk menggambarkan persepsi responden atas itemitem pengukuran yang diajukan (Rangkuti, 2002).

\subsubsection{Analisis Statistik Deskriptif Variabel Periklanan}

Dari hasil hitungan, diperoleh indeks tanggapan responden terhadap variabel periklanan sebesar 79.67 persen. Artinya, periklanan melalui katalog memperoleh tanggapan responden yang tinggi dan positif.

\subsubsection{Analisis Statistik Deskriptif Variabel Promosi Penjualan}


Dari hasil hitungan, diperoleh indeks tanggapan responden terhadap variabel promosi penjualan sebesar 80.28 persen. Artinya, promosi penjualan melalui pemberian potongan harga sewa memperoleh tanggapan responden yang tinggi dan positif.

\subsubsection{Analisis Statistik Deskriptif Variabel Penjualan Pribadi}

Dari hasil hitungan, diperoleh indeks tanggapan responden terhadap variabel penjualan pribadi sebesar 80.25 persen. Artinya, promosi penjualan melalui agen marketing memperoleh tanggapan responden yang tinggi dan positif.

\subsubsection{Analisis Statistik Deskriptif Variabel Pemasaran Langsung}

Dari hasil hitungan, diperoleh indeks tanggapan responden terhadap variabel pemasaran langsung sebesar 80.19 persen. Artinya, pemasaran langsung melalui customer service memperoleh tanggapan responden yang tinggi dan positif.

\subsection{Analisis Efektivitas Bauran Promosi Dengan Metode EPIC Model}

Menurut Rangkuti (2002), untuk menentukan posisi tanggapan responden dengan menggunakan nilai skor setiap variabel perlu untuk ditentukan rentang skala penilain. Bobot alternatif jawaban yang terbentuk dari teknik skala peringkat terdiri dari kisaran antara 1 hingga 5, dengan demikian skala penilaian sebesar:

$$
\begin{aligned}
& R s=\frac{R(\text { bobot })}{M} \\
& R s=\frac{5-1}{5}=0.8
\end{aligned}
$$

Sehingga dapat diuraikan skala penilaian menjadi:

$1.00-1.80$ = Sangat tidak efektif (STE)

$1.81-2.60=$ Tidak efektif $(\mathrm{TE})$

$2.6-3.40=$ Cukup efektif $(\mathrm{CE})$

$3.41-4.20=$ Efektif $(\mathrm{E})$

$4.21-5.00=$ Sangat efektif $(\mathrm{SE})$

Diagram 1. Skala penilaian efektivitas.

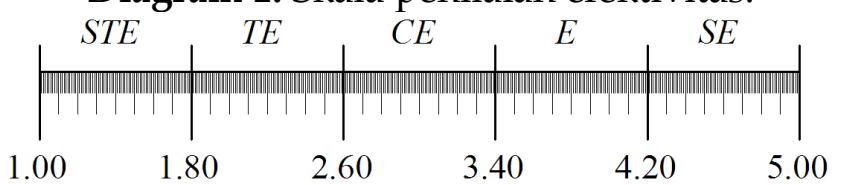

\subsubsection{Analisis Efektivitas Masing-Masing Variabel}

A. Periklanan

Secara keseluruhan EPIC rate, rata-ratanya adalah 3.99, artinya periklanan yang diterapkan pada hotel The Lombok Lodge sudah efektif dilakukan. Secara keseluruhan diagram hasil analisis efektivitas periklanan dengan metode EPIC model.

Diagram 2. EPIC model efektivitas periklanan 
B. Promosi penjualan

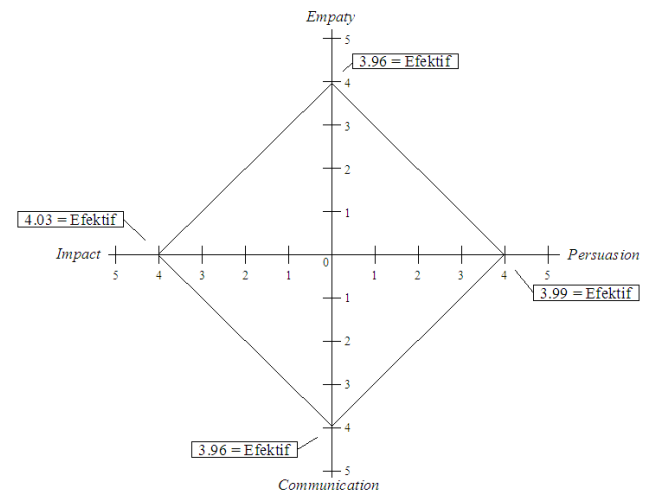

Secara keseluruhan EPIC rate, rata-ratanya adalah 4.01, artinya promosi penjualan yang diterapkan pada hotel The Lombok Lodge sudah efektif dilakukan. Secara keseluruhan diagram hasil analisis efektivitas promosi penjualan dengan metode EPIC model dapat dilihat pada Diagram 4.11 .

Diagram 3. EPIC model efektivitas promosi penjualan

C. Penjualan pribadi

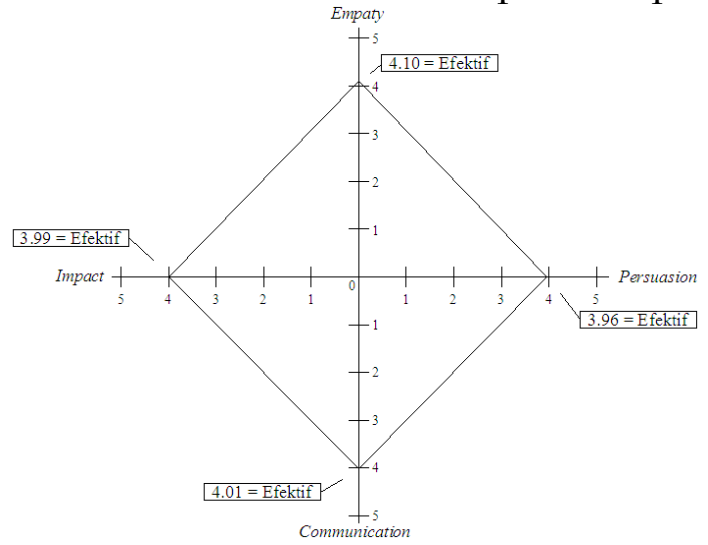

C.1 Dimensi empathy variabel penjualan pribadi

Secara keseluruhan EPIC rate, rata-ratanya adalah 4.01, artinya penjualan pribadi yang diterapkan pada hotel The Lombok Lodge sudah efektif dilakukan. Secara keseluruhan diagram hasil analisis efektivitas penjualan pribadi dengan metode EPIC model dapat dilihat pada Diagram 4.16 .

Diagram 4. EPIC model efektivitas penjualan pribadi

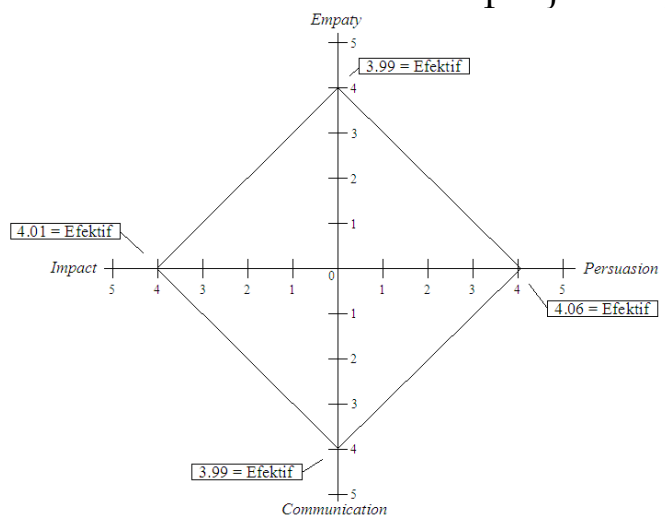


D. Pemasaran langsung

Secara keseluruhan EPIC rate, rata-ratanya adalah 4.01, artinya pemasaran langsung yang diterapkan pada hotel The Lombok Lodge sudah efektif dilakukan. Secara keseluruhan diagram hasil analisis efektivitas pemasaran langsung dengan metode EPIC model dapat dilihat pada Diagram 4.21 .

Diagram 4.21 EPIC model efektivitas pemasaran langsung

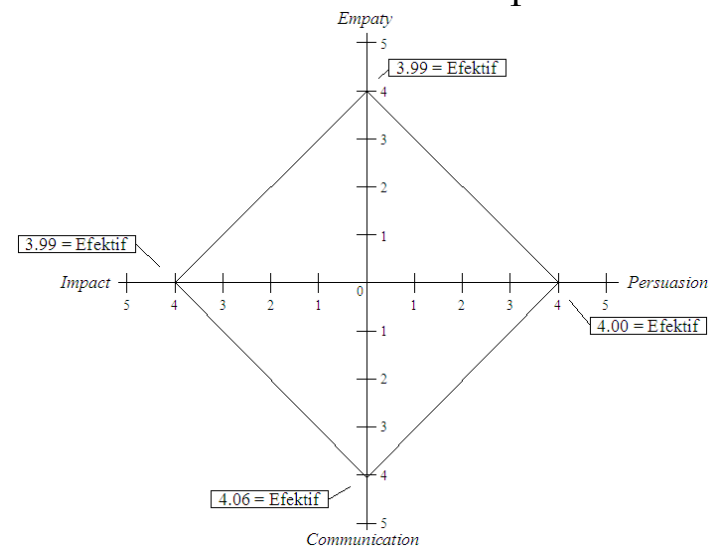

\subsubsection{Analisis Efektifitas Bauran Promosi}

Secara keseluruhan rata-rata nilai EPIC adalah 4.01, artinya pelaksanaan bauran promosi yang diterapkan pada hotel The Lombok Lodge sudah efektif dilakukan.

\section{Kesimpulan Dan Saran}

\subsection{Kesimpulan}

Berdasarkan pembahasan dalam bab IV dapat ditarik kesimpulan sebagai berikut:

1. Secara keseluruhan pelaksanaan bauran promosi pada hotel The Lombok Lodge telah efektif, terbukti dari hasil analisis EPIC Model secara keseluruhan sebesar 4.01, nilai tersebut masuk dalam rentang skala penilaian 3.41 - 4.20 (Efektif).

2. Hasil analisis EPIC Model variabel Periklanan sebesar 3.99, nilai tersebut masuk dalam rentang skala penilaian 3.41 - 4.20 dan nilai tersebut dinyatakan telah efektif.

3. Hasil analisis EPIC Model variabel Promosi Penjualan sebesar 4.01 nilai tersebut masuk dalam rentang skala penilaian $3.41-4.20$ dan nilai tersebut dinyatakan telah efektif.

4. Hasil analisis EPIC Model variabel Penjualan Pribadi sebesar 4.01 nilai tersebut masuk dalam rentang skala penilaian $3.41-4.20$ dan nilai tersebut dinyatakan telah efektif.

5. Hasil analisis EPIC Model variabel Pemasaran langsung sebesar 4.01 nilai tersebut masuk dalam deretan skala penilaian $3.41-4.20$ dan nilai tersebut dinyatakan telah efektif. 


\section{Daftar Pustaka}

Aaker David A (1991), Managing Brand Equity, Capitalyzing on the Value of a Brand Name, The Free Press:New York.

Agung, Wahyu (2010), Panduan SPSS 17.0 Untuk Mengolah Penelitian Kuantitatif, Cetakan Pertama, Gara Ilmu, Jogjakarta.

Amstrong Gary (2001), Principle of Marketing, Edisi 9, Prentice Hall International, New Jersey.

Basu Swastha (1991), Pengantar bisnis Modern, $3^{\text {rd }}$ Edition, Liberty, Yogyakarta.

Boulton R. William (1984), Business Policy, the art of strategic management, McMilan, New York.

Darmadi Durianto, Sugiarto, Anton. W.Widajaj, Hendrawan.S. (2003), Invasi Pasar Dengan Iklan Yang Efektif, PT.Gramedia Pustaka Utama, Jakarta

Erik Salim (2011), Bauran Pemasaran Marketing Mix, tersedia di http://www.wealthindonesia.com/lain-lain/bauran-pemasaranmarketing-mix (diakses 5 Juni 2011).

Jhon A. Howard, Robert P. Shay danChristopher A. Green (1998), Measuring The Effect of Marketing Information onBuying Intentions, Journal of Servise Marketing, Galeria Mall White Plains, New York.

Philip Kotler (1994), Marketing Management; Analysis,Planning, Implementation and Control, Eighth Edition.

Rangkuti, Freddy (2009), Mengukur Efektivitas Program Promosi (Analisa Kasus Menggunakan SPSS), PT. Gramedia Pustaka Utama, Jakarta.

Robert J Lavidge and Gary A Steiner (1961), A Model for Pedictive Measurement of Advertising Effectiveness, Journal of Marketing.

Simamora, Henry (2002), Manajemen Pemasaran International, Jilid 2, Salemba Empat, Jakarta. 